\title{
Homeobox Protein Aristaless-Like 4
}

National Cancer Institute

\section{Source}

National Cancer Institute. Homeobox Protein Aristaless-Like 4. NCI Thesaurus. Code C74967.

Homeobox protein aristaless-like 4 (411 aa, $\sim 44 \mathrm{kDa}$ ) is encoded by the human ALX4 gene. This protein is involved in the regulation of transcription during skull and limb development. 